\title{
Impact of Internal Corporate Governance on Capital Cost in Jordanian Pharmaceutical Companies
}

\author{
AbedAlwahab Mahmoud AL-Rawashdeh ${ }^{1,2}$ \\ ${ }^{1}$ Assistant Professor of Accounting, Faculty of Economics and Administrative Sciences, Jordan \\ ${ }^{2}$ Zarqa University in Jordan, Zarqa University, Zarqa, Jordan \\ Correspondence: AbedAlwahab Mahmoud AL-Rawashdeh, Assistant Professor of Accounting, Faculty of \\ Economics and Administrative Sciences, Jordan. E-mail: arawashdeh@zu.edu.jo
}

Received: March 20, 2019

Accepted: April 28, 2019

Online Published: May 5, 2019

doi:10.5539/ijef.v11n6p83

URL: https://doi.org/10.5539/ijef.v11n6p83

\begin{abstract}
The study aims to find the impact of internal corporate governance on capital in Jordanian's Pharmaceutical Companies. The data was collected through distributing a questionnaire to the leading positions staff in the sample companies in addition to external auditor.

The study found that there is an impact on the principles of the internal corporate governance represented by the board directors, ownership structure, internal control and disclosure (combined and sporadic) on the capital cost, where good corporate governance can reduce the capital cost in Jordanian Pharmaceutical Companies.

The researchers recommended paying more attention for various corporate governance elements, conducting more studies to find the impact of governance on performance and increasing the attention and promotion of rules of governance by the relevant authorities to urge companies to abide by them.
\end{abstract}

Keywords: internal corporate governance, capital cost

\section{Introduction}

The successive financial crises happened in many countries in North America, Asia and Europe have led to increased interest in corporate governance, especially after the economic collapse for many giant companies that occurred at the end of the last century and at the beginning of this one, where many scholars and researchers refer it to weak corporate governance. (Asian Development Bank Institute, 2004).

Corporate governance is rooted to the beginning of the 19th century, when public shareholding companies emerged; these new form of companies came with the problems of separation of ownership from management, which led to the emergence of what is known today as the theory of the agency (Jensen et al., 1976).

Agency theory refers to the conflict of interest between company management and shareholders and the need to set rules and control measures that limit the company management tyranny and preserve shareholders money and equity. Studies have shown that good corporate governance leads to improved performance at the company, (Jerab, 2009), it also leads to increasing the stock's price and thus increasing the company's market value, (Garmese et al., 2004), since investors are willing to pay a higher price for companies that have good corporate governance knowing that their investments in such companies will not be exposed to risk or that the risks are significantly low. The studies show this is due to that good governance leads to reducing the agency's cost (Kiven et al., 2009).

\subsection{Study Significance}

The main purpose of this study lies in its serious attempt to demonstrate the impact of internal corporate governance on the capital cost in Jordanian pharmaceutical companies, where some researchers have already shown the impact of corporate governance on performance, reliability of financial reports or on many others, but this study attempts to demonstrate the impact of internal corporate governance on the capital cost and answer the question: Does a good internal governance increase or decrease cost?

\subsection{Study Problem}

Most companies are applying corporate governance principles in general; these principles include internal corporate governance principles to ensure the efficient operations, reliability of financial statements, compliance 
with laws and regulations, as well as company's assets preservation. However, the question is: What is the impact of this on company that undertakes applying the principles of internal corporate governance and the following sub-questions arise from this question:

1) What is the impact of the concentration of ownership on capital cost in Jordanian pharmaceutical companies?

2) What is the impact of Board of Directors on capital cost in Jordanian pharmaceutical companies?

3) What is the impact of internal control and audit on capital cost in Jordanian pharmaceutical companies?

4) What is the impact of disclosure and transparency on capital cost in Jordanian pharmaceutical companies?

\subsection{Study Hypotheses}

According to study problem and its questions the study hypotheses are determined as the following:

First Hypothesis:

There is no statistically significant impact of internal corporate governance ( average of internal governance principles) on capital cost in Jordanian pharmaceutical companies listed on Amman Stock Exchange at significance level $(\alpha=0.05)$.

\section{Second Hypothesis:}

There is no statistically significant impact of internal corporate governance (independent variable) represented by the following dimensions: ownership structure, board of directors, internal control and disclosure, on capital cost (dependent variable) in Jordanian pharmaceutical companies.

\subsection{Study Model}

\section{Dependent Variable}

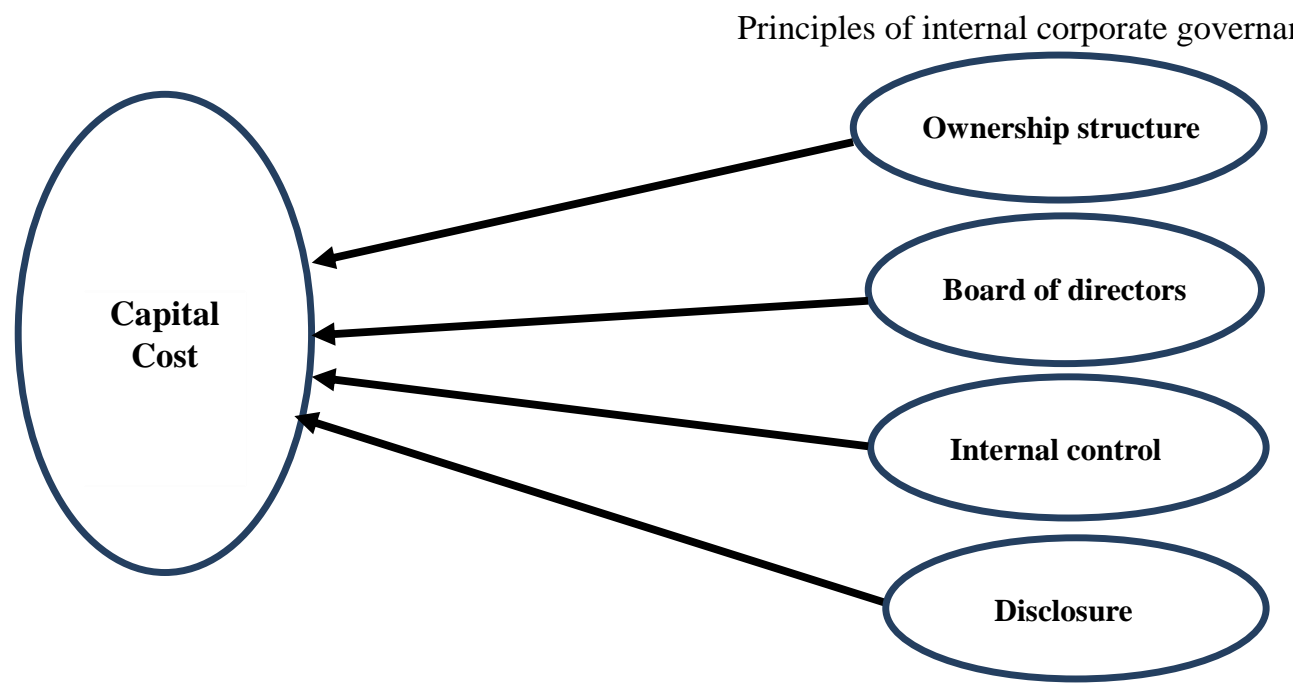

\section{Literature Review}

There were many studies regarding Corporate governance and in 2007 "ALJUAYDI" in his study which aimed to adapting and applying the model to measure Corporate governance level in Jordan then to measure the relation between Corporate governance level and the corresponding institutional performance (financial performance, operational performance, stocks performance and market performance).

In this study which used questions to collect data that governance strongly effect on financial, operational and stocks performance with significant variation in this effect among different sectors

The study also shows that governance effect was insignificant on market value for sample companies, and it recommended developing (CLAS) model which used to measure how corporate governance is applied in companies.

In 2008 (Al-shareef) refer in study aimed to determine the relation between Corporate governance and profit quality that there is inverse relation between the directors board ownership and profit quality. On the other hand Positive relationship found between the independence Audit Committee and the quality of profits. For the 
remaining governance elementsthe statistical tests shows no relation between them and profit quality.

In (Bahjat \& Brain, 2008) study that aimed to determine how to measure companies governance and show the type of relation between companies governance and facility performance, where the researchers reviewed accounting literature in this regard to find the relation type between directors board ownership for company stocks and the separation the management from ownership from one side and company performance from the other side, and relation found to be positive.

Jereb's study (Jereb, 2009) tried to find impact of internal Corporate governance on capital cost as he pointed out that Corporate governance has significant impact on facility performance, where facility performance was measured through financial performance, facility growth rate, efficiency and risk reduction, and the result shows in Turkey significant impact for Corporate governance on facility performance specially on mid and long term while insignificant at short term.

\section{Concept of Corporate Governance}

Governance defined as group of operations, policies and roles that affect the way that organization operates. In 2003 (Matheson) defined the Corporate governance as the way to find out how to ensure that management will work according to the lows and regulations and deal fairly with all stakeholders.

OECD - Organization for Economic Co-operation and Development defined the governance as the relations between company management, directors' board, owners and stakeholders, where the company can determine the best way to achieve target, monitor performance and results.

Applying corporate governance in companies lead to increase operational efficiency, financial reports reliability, compliance with lows and regulations and maintain company assets (Jerb 2009).

Researchers, scholars and stakeholders agreed that the general principles of Corporate governance consist of preserving the equities of shareholders and customers, ensuring the principle of effective management, ensuring power sharing between the administrative and supervisory Commits of the company, implementing appropriate controls measures on financial and economic activity, ensuring full disclosure and transparency, applying lows and regulations and taking into truth and morality principles.

The corporate governance concerned parties are directly and indirectly involve managing corporate operations , parties include (CEO, Directors board, external audits, stakeholders), while Governance stakeholders are suppliers, corporate employees, creditors, customers, government agencies, media and society in general (Klapper et al., 2002). But the most concerned in governance is company owners, company directors of board (whom are the custodians of the company and the assets) and CEO whom authorized to use company assets.

Business literature points out that the core rules of corporate governance are:

1) Accountability, which means ensuring that the management of the organization is directly responsible for all decisions and actions they took taken before the board of directors, while the Board of Directors is directly responsible for all decisions and actions they took before public body (shareholders).

2) Equity, which ensure that all shareholders, including holders of non-controlling rights, are treated fairly.

3) Disclosure, which means disclosure of all financial and non-financial transactions that affect the company, performance and ownership in a timely manner.

4) Independency, by ensuring that all regulations and organizational structure are in a position to prevent or minimize the conflicts of interest between the various parties, in addition to the administration independency make decisions without being affected by external pressures.

\section{Study Methodology and Data Resources}

The researchers followed the analytical descriptive approach, as it is fit with the purpose of study and the standard quantitative approach which was used in data analysis and presentation through different statistical methods. Statistical Packages for Social Sciences (SPSS) software was used in this study.

\subsection{Data Resources}

Study Society: consists of all Jordanian pharmaceutical companies listed on the Amman Stock Exchange for the year 2014, and companies that do not have information for this year were excluded. 6 companies meet study conditions.

Study Sample: consisted of all the companies that met the requirements (comprehensive inventory). The questionnaire was distributed to a member of the board of directors, head of the internal control department and 
head of the accounting department in each of the sample companies.

\title{
4.2 Study Variables
}

\section{Independent Variables}

1) Capital ownership structure (SC)
2) Board of directors (BD)
3) Internal control (IC)
4) Disclosure (DIS)

\section{Dependent Variables}

1) Capital $\operatorname{cost}(\mathrm{r})$

\section{Controlled Variables}

\author{
1) Risk factor (Beta) \\ 2) book value to market value ratio (BM) \\ 3) Book value (BV) \\ 4) Market value (MV) \\ 5) Inflation rate (INEL)

\subsection{Method and Procedures}

Accounting literature and previous studies indicate that capital cost is affected by a number of factors, including risk factors as well as the characteristics and nature of the facility (Fama \& French, 1992).

The Capital Asset Pricing Model (CAPM) has demonstrated a positive correlation between the capital cost and beta factor and the book value to market value as used in (Fama-Frensh Three-factor model, 1992), Gerhardt et al. (2001) model and (Gode \& Mohanram, 2002) model. While the remaining variables (book value, market value and inflation) were used in addition to previous variables by (Kiven et al., 2009).

\subsubsection{Internal Corporate Governance Measurement}

To measure corporate governance in the sample companies, the researchers (Kevin et al., 2009 as an example) used the questionnaire to collect the information needed for the measurement process, using the questionnaire designed by the Crédit Lyonnais Institution of Financial Management in Asia (CLNA), which is used to measure corporate governance.

The researchers modified the questionnaire to suit the Jordanian corporate environment where one point was given for each positive answer and zero to the negative one. Thus, the average of the corporate governance of each of the governance elements can be calculated as well as the average governance of the company for both the board principle and the internal control principle and the principle of disclosure in accordance with equation (1):

$$
D S=\frac{1}{n} \sum_{i=1}^{n} d i
$$

Where

DS: disclosure rate in the company

$\mathrm{d} i$ : Number of Vocabularies that have been disclosed

$\mathrm{n}$ : total number of Vocabularies.

In the capital ownership structure, studies have shown that property dispersion has a positive effect on the choice of conservative accounting policies, which limits the majority to exploit the minority and to engage in beneficial behavior by over-estimating profits and assets and thus issuing a conservative financial report which impact the capital cost (Yousef, 2012)

The ownership structure will be measured by knowing the concentration Percentage of ownership of the company's capital to the top five shareholders of each sample study companies. And In order to ascertain the consistency and consistency of the questionnaire, the Cronbach's Alpha equation was used where the average was $(89.6 \%)$ and this indicates that the internal consistency of the study is good. 
The researchers chose Easton methodology to measure the capital cost in this study for its accuracy and ease:

$$
\mathrm{r}=\sqrt{\frac{e p S_{t+2}-e p S_{t+1}}{p_{t}}}
$$

Where:

r: The Capital cost

$\mathrm{eps}_{\mathrm{t}+1}$ : Forecasted One Year-ahead Earnings per share

$\mathrm{eps}_{\mathrm{t}+2}$ : Forecasted two Year-ahead Earnings per share

P: current stock price

The expected earnings per share for the coming year and next are calculated by calculating the average earnings for the previous five years for both year and the following year.

\subsubsection{Accounting Variables Measurement}

Information on variables control was obtained from the companies' financial statements published on the ASE (Amman stocks exchange) website at the end of 2014.

Inflation rate obtained from the Department of Statistics. For the risk rate (BETA) for each company in study sample was calculated by the researchers since its data was unavailable on competent authorities according to below equation

$$
\beta=\operatorname{cov}(R s R m) / \sigma^{2} R M
$$

Where

$\beta$ : Risk factor (Beta).

Rs :company return.

MR: Return of the market portfolio.

$\mathrm{Rs}^{2}$ : Variance coefficient of return of the company.

$\sigma^{2} \mathrm{RM}$ : Variance coefficient of return of market return.

$\sigma \mathrm{Rm}$ : Standard deviation of market returns.

cov (RsRm): The common variance between the Rs return and the market return $\mathrm{m} \mathrm{R}$ is the sum of the correlation coefficient (r) with both the standard deviation of the return of $\sigma$ Rs and the standard deviation of the market yield $\mathrm{Rm} \sigma$.

4.3.3 Measuring the Impact of Independent Variables on the Capital Cost

Accounting literature used different mathematical models to measure the impact of Corporate governance on the capital cost. Among these models is the model used by Kevin (et al., 2009), which will be used in this study for its simplicity and ease of application. The model is as follows:

$$
R_{j, t}=\beta C G_{j, t}+\sum^{\gamma} \text { control }_{j, t}+\varepsilon_{j, t}
$$

Where

R: capital cost;

GC: Rate of internal governance principles;

Controls: Controlled Variables;

j: Organization;

$\mathrm{t}$ : Year or financial period.

The internal corporate governance principles instead of CG will be compensated and the control variables will be replaced instead of the control to test hypotheses (Kevin et al., 2009) as follows:

\section{1) First hypothec}

$$
R_{j, t}=\beta_{0}+\beta_{1} C G_{j, t}+\beta_{2} B E T A_{j, t}+\beta_{3} B M_{j, t}+\beta_{4} B V_{j, t}+\beta_{5} I N F L_{j, t}+\beta_{6} M V_{j, t}+\varepsilon_{j, t}
$$

2) Second hypothec

$$
R_{j, t}=\beta_{0}+\beta_{I} S C_{j, t}+\beta_{2} B D_{j, t}+\beta_{3} I C_{j, t}+\beta_{4} D I S_{j, t}+\beta_{5} B E T A_{j, t}+\beta_{6} B M_{j, t}++\beta_{7} B V_{j, t}+\beta_{8} I N F L_{j, t}+\beta_{9} M V_{j, t}+\varepsilon_{j, t}
$$




\section{Descriptive Analysis of Study Sample}

All Jordanian pharmaceutical companies listed on the Amman Stock Exchange (ASE) were selected. Table 1 shows the names of these companies and information related thereto.

Table 1. Names of Jordanian pharmaceutical companies

\begin{tabular}{ccc}
\hline Capital (million) & Date of Establishment & The Company's name \\
\hline 20.0 & 1975 & Dar Al Dawa for Development and Investment \\
20.0 & 2004 & Jordan Pharmaceutical Company \\
9.5 & 1994 & Al Hayat Pharmaceutical Industries Middle East Pharmaceutical Industries \\
5.0 & 1983 & Arab Center for Pharmaceutical Industries \\
5.00 & 2009 & Philadelphia Pharmaceuticals \\
9.87 & 1993 & Middle East Pharmaceutical Industries \\
\hline
\end{tabular}

Table 2 shows the mean, standard deviation, the largest and smallest value of independent and controlled study variables. We note from the below table the high rate of internal corporate governance principles in the Jordanian pharmaceutical companies, with internal control at $76 \%$ and the Board of Directors in second place, disclosure and ownership structure.

Table 2. Descriptive statistics of study variables

\begin{tabular}{|c|c|c|c|c|}
\hline The smallest value & The largest value & standard deviation & Arithmetic mean & variable \\
\hline 0.14 & 0.18 & 780 & 0.16 & $\mathrm{R}$ \\
\hline 0.17 & 980. & 0.27 & 0.63 & $\mathrm{SC}$ \\
\hline 610. & 870. & 060. & 740. & $\mathrm{BD}$ \\
\hline 610. & 880. & 0.07 & 0.76 & $\mathrm{IC}$ \\
\hline 600. & 820. & 070. & 720. & DIS \\
\hline 1.10 & 3.06 & 310. & 1.74 & BETA \\
\hline 6.52 & 9.23 & 750. & 7.35 & $\log (B V)$ \\
\hline 0.71 & 9.19 & 1.85 & 2.30 & BM \\
\hline 5.50 & 5.50 & 5.50 & 5.50 & INFL \\
\hline 8.62 & 6.13 & 210. & 7.11 & $\log (\mathrm{MV})$ \\
\hline
\end{tabular}

Table 3 shows the relationship (Pearson correlation coefficient) between the different independent variables, the dependent variable and the independent variables all together

Table 3. Matrix of correlation coefficients among variables

\begin{tabular}{ccccccccccc}
\hline & $\mathrm{R}$ & $\mathrm{SC}$ & $\mathrm{BD}$ & $\mathrm{IC}$ & $\mathrm{DIS}$ & BETA & BM & BV & INFL & MV \\
\hline r & & $136 .-$ & 240. & $696 .-$ & $633 .-$ & 0.212 & 0.030 & $163 .-$ & 399. & 0.115 \\
SC & $136 .-$ & & 0.144 & 009. & 066. & $164 .-$ & $139 .-$ & 04. & $297 .-$ & 0.343 \\
BD & 240. & 144. & & 057. & 130. & $076 .-$ & 254. & 401. & -135. & 0.422 \\
IC & $696 .-$ & 009. & 057. & & 559. & $068 .-$ & 004. & 378. & $153 .-$ & 0.096 \\
DIS & $633 .-$ & 066. & 130. & 559. & & $284 .-$ & $01 .-$ & 165. & 097. & 0.316 \\
BETA & 212. & $164 .-$ & $076 .-$ & $068 .-$ & $284 .-$ & & $136 .-$ & 132. & $097 .-$ & 0.054 \\
BM & 030. & $139 .-$ & 254. & 004. & $01 .-$ & $136 .-$ & & 359. & $038 .-$ & 0.297 \\
BV & $163 .-$ & 040. & 401. & 378. & 165. & 132. & 359. & & 098. & 0.313 \\
INFL & 399. & $287 .-$ & 135. & $153 .-$ & $073 .-$ & 097. & $038 .-$ & 098. & & 0.182 \\
MV & $0.226-$ & 0.082 & 0.037 & 0.277 & 0.091 & $0.314-$ & $0.111-$ & $0.093-$ & $0.172-$ & \\
\hline
\end{tabular}

Table 3 shows a negative correlation between the capital cost and the principles of corporate governance except for the board of directors (BD), where the relationship is positive. The table also showed a negative correlation between capital cost (DIS) and project size (FM). In addition, there is a positive correlation with BETA, and book value to market value ratio (BM) to inflation ratio.

These relationships are reasonable and predictable. For example, the capital cost increases as the value of the beta increases, which represent the risk factor, but decreases as the capital of the company increases.

These results are consistent with (Kevin et al., 2009) and (Jerab2009) studies. 


\section{Testing Hypotheses}

The rule of decision to reject or accept hypotheses:

Multiple linear regressions have been used to test the hypotheses of this study. The value of P-value Sig was used as the smallest test level to measure statistical morale. It came as an alternative to the traditional test that compares the (F) table at a specified value and the calculated value of $(\mathrm{F})$, so the rule of decision is as follows:

- We do not reject the null hypothesis (Ho) if P-Value Sig is greater than the error rate (predefined level of morale) required $(0.05)$ and reject alternative hypothesis $\left(\mathrm{H}_{1}\right)$.

- We reject the null hypothesis (Ho) if P-Value Sig is less or equal to the error rate (the predefined level of morale) required (0.05) and reject the alternative hypothesis $\left(\mathrm{H}_{1}\right)$.

\subsection{Testing First Hypothesis}

- There is no statistically significant impact of internal corporate governance (average of internal corporate principles) on capital cost in listed companies of Jordanian pharmaceutical industry at significance level of ( $\alpha \leq$ $0.05)$.

After the researchers conducted the necessary mathematical analysis of the data on internal corporate governance in the study sample companies so as to become appropriate and compatible with the purposes of this study, the researchers used multiple regression analysis to determine the impact of corporate governance principles combined, on capital cost according to equation (5). Whereas the rate of internal corporate governance principles was found combined, and the results of this analysis showed that the total of what is explained by dimensions of independent variables regarding capital cost variable variance (r) was (0.504) as shown in Table 4 (Summary of regression analysis).

Table 4. Summary of regression analysis

\begin{tabular}{|c|c|c|c|c|c|c|c|c|c|}
\hline \multirow[t]{2}{*}{ Model } & \multirow[t]{2}{*}{$\mathrm{R}$} & \multirow[t]{2}{*}{ R Square } & \multirow[t]{2}{*}{ Adjusted R Square } & \multirow{2}{*}{$\begin{array}{l}\text { Std. Error of The } \\
\text { Estimate }\end{array}$} & \multicolumn{5}{|c|}{ Change Statistics } \\
\hline & & & & & R Square Change & F change & df 1 & Df 2 & Sig \\
\hline 1 & 0.801 & 0.641 & 0.504 & 0.54864 & 0.641 & 4.690 & 5 & 24 & 0.002 \\
\hline
\end{tabular}

a. Predictors: (Constant), MV, BD, BETA, BM, INFL,CG.

The results shown in the variance analysis table (ANOVA) Table 5 indicate that the value of (P-Value Sig) is $(0.002)$ which is statistically significant at level $(\alpha)$ which equals to or less than $(0.05)$, therefore, we reject the null hypothesis $(\mathrm{H} 0)$ that assumes there is no impact of internal corporate governance on capital cost in Jordanian pharmaceutical companies and we do not reject the alternative hypothesis (H1) that indicates there is an impact of internal corporate governance on capital cost.

Table 5. Analysis of variance (ANOVA)

\begin{tabular}{llllll}
\hline Model & Sum of square & df & MEAN Square & F & Sig \\
\hline 1 Regression & 11.293 & 5 & 1.412 & 4.690 & 0.002 \\
Residual & 6.321 & 24 & 0.301 & & \\
Total & 17.614 & 29 & & & \\
\hline
\end{tabular}

a. Predictors: (Constant), INFL, BM, BD, BETA, MV,CG; b. Dependent Variable: r.

The BETA values shown in Table 6 show that coefficient value of corporate governance variable is $(-0.116)$ which is statistically significant at a level below (0.05), while the coefficient of independent variable BETA is $(0.360)$ which is not statistically significant, but for the rest of variables they have negative values, meaning that they reduce capital cost and were statistically significant except for inflation variable (INFL) where it was positive and leading to increasing capital cost which is also statistically significant.

Table 6. Result of multiple regression analysis

\begin{tabular}{|c|c|c|c|c|c|c|}
\hline \multicolumn{7}{|c|}{ Coefficients } \\
\hline \multirow{2}{*}{$\begin{array}{c}\text { Dependent Variable } \\
\text { Y } \\
\end{array}$} & \multicolumn{6}{|c|}{ Independent Variables } \\
\hline & B Fixed standard limit & $\mathrm{CG}$ & BETA & $\mathrm{BM}$ & INFL & MV \\
\hline Coefficient Value & 14.256 & -0.116 & 0.360 & -0.097 & -0.096 & -0.185 \\
\hline t-test value & 5.531 & -0.975 & 3.125 & -0.136 & 1.825 & 1.609 \\
\hline Morality & 0.000 & 0.020 & 0.334 & 0.027 & 0.015 & 0.037 \\
\hline
\end{tabular}




\subsection{Testing Second Hypothesis}

There is no impact of internal organizational governance principles (independent variable) represented by the following dimensions: ownership structure, board of directors, internal control and disclosure of capital cost (dependent variable) in Jordanian pharmaceutical companies.

Multiple regression analysis was used to determine the impact of internal governance principles (ownership structure, board of directors, internal control and disclosure) on capital cost, in accordance with equation (6).

The results of this analysis show that the sum of what the variables explain (independent variables) about the variance of capital cost variable (r) is (0.644) as shown in Table 7. This means that independent variables used in this study can explain through the proposed model the value of $(0.644)$ of variance in dependent variable which is capital cost (r). This indicates the linear relationship of the proposed model.

Table 7. Summary of regression analysis

\begin{tabular}{|c|c|c|c|c|c|c|c|c|c|}
\hline \multirow[t]{2}{*}{ Model } & \multirow[t]{2}{*}{$\mathrm{R}$} & \multirow[t]{2}{*}{ R Square } & \multirow[t]{2}{*}{ Adjusted R Square } & \multirow{2}{*}{$\begin{array}{l}\text { Std. Error of } \\
\text { The Estimate }\end{array}$} & \multicolumn{5}{|c|}{ Change Statistics } \\
\hline & & & & & R Square Change & F change & df 1 & Df 2 & Sig \\
\hline 1 & 0.869 & 0.755 & 0.644 & 0.46469 & 0.755 & 6.841 & 5 & 24 & 0.000 \\
\hline
\end{tabular}

a. Predictors: (Constant), MV, BD, DIS, SC, BM, INFL, BETA, MV, IC.

The results shown in regression analysis (ANOVA) Table (8) indicate that the value of (P-Value Sig) is $(0.000)$ and that it is statistically significant at $(\alpha)$ level, which is equal to or less than $(0.05)$. Therefore, we reject the null hypothesis $\left(\mathrm{H}_{0}\right)$ that assuming there is no impact of internal corporate governance on capital cost in Jordanian pharmaceutical companies and we do not reject the alternative hypothesis $\left(\mathrm{H}_{1}\right)$, which indicates that there is an impact of internal organizational governance on capital cost.

Table 8. Analysis of variance of regression

\begin{tabular}{|c|c|c|c|c|c|}
\hline \multicolumn{6}{|c|}{ ANOVA } \\
\hline Model & Sum of square & df & Mean Square & $\mathrm{F}$ & Sig \\
\hline 1 Regression & 13.295 & 9 & 1.477 & 6.841 & 0.000 \\
\hline Residual & 4.319 & 20 & 0.216 & & \\
\hline Total & 17.614 & 29 & & & \\
\hline
\end{tabular}

a. Predictors: (Constant), MV, BD, DIS, SC, BM, INF, BETA, IC; b. Dependent Variable: $r$

It is clear from multiple regression analysis table that the estimated coefficients for independent variable, which is (internal control) (IC) is (-0.403) which is the most significant impact among independent variables and it has a statistically significant at the level below (0.05), followed by the independent variable that has an impact, which is disclosure (DIS), where its estimated value is $(-0.390)$ which is also statistically significant.

The third variable is the independent variable which is capital structure (SC), with an estimated value of (-0.072) but it is not statistically significant.

For independent variable, which is the board of directors (BD) its estimated value is (0.342), which is statistically significant, but it has appositive value, meaning that this variable leads to increasing in capital cost, so the researchers believes that this is due to the lack of independency of the boards of directors in some companies where some members boards of directors occupy executive positions at their companies.

Table 9. Result of multiple regression analysis

\begin{tabular}{llllll}
\hline \multirow{2}{*}{ Dependent Variable } & \multicolumn{5}{c}{ Independent Variables } \\
\cline { 2 - 6 } y & B Fixed standard limit & SC & BD & IC & DIS \\
\hline Coefficient Value & 18.122 & -0.072 & 0.347 & -0.403 & -0.390 \\
t-test value & 7.097 & -0.578 & 2.697 & 2.531 & 2.695 \\
Morality & 0.000 & 0.504 & 0.014 & 0.020 & 0.014 \\
\hline
\end{tabular}

\section{Conclusions and Recommendations}

\subsection{The Study Results}

1) There is a negative and statistically significant impact of the independent variables combined: (Arithmetic mean for level of applying internal governance principles: board of directors, ownership structure, internal 
control and disclosure) on capital cost in Jordanian Pharmaceutical Companies.

2) There is a positive statistical significance of board of directors on capital cost in Jordanian pharmaceutical companies.

3) There is a negative impact of structure of capital ownership on capital cost in Jordanian pharmaceutical companies, but it is not statistically significant.

4) There is a statistically significant negative impact of internal control on capital cost in Jordanian pharmaceutical companies.

5) There is a negative impact that is statistically significant of disclosure on capital cost in Jordanian pharmaceutical companies.

\subsection{Recommendations}

Based on the study findings, the researchers recommend the following:

1) Increasing promotion of corporate governance by the concerned authorities to encourage Jordanian companies to implement principles and rules of corporate governance.

2) Conducting further studies to determine impact of corporate governance on performance of Jordanian companies.

3) Finding a regulatory body to measure the extent in which companies are contributing to corporate governance in general, and internal governance in particular, this helps companies to know the extent in which they apply the principles of governance.

4) Election and appointment of members of the board of directors with the proper knowledge and experience, to be independent and do not perform executive work in the company.

\section{References}

Al-Sherif, I. (2008). Profit Quality and its Relationship to Institutional Governance: An Applied Study on Industrial Companies Contributing to the Amman Stock Exchange (unpublished PhD thesis). Arab Academy for Banking and Financial Sciences, Amman, Jordan.

Asian Development Bank Institute. (2004). Devolution in Pakistan, Overview of the ABD/DFID/ World Bank study.

Biswas, P., \& Bhuiyan, H. (2008). Corporate Governance and Firm performance: Theory and Evidence from Literature. Working Paper. https://doi.org/10.2139/ssrn.1257617

Botosan, C., \& Plumlee, M. (2002). Assessing the Construct Validity of Alternative Proxies for Expected Cost of Equity Capital. Accounting Review, forthcoming. https://doi.org/10.2139/ssrn.310181

Chen, K. C. W., Chen, Z. H., \& Wei, K. C. J. (2008). Agency costs of free cash flow and the effect of shareholder rights on the implied cost of equity capital. Working paper, Hong Kong University of Science and Technology.

Claus, J., \& Thomas, J. (2001). Equity premia as low as three percent? Evidence from analysts' earnings forecasts for domestic and international stock markets. Journal of Finance, (56), 1629-1666. https://doi.org/10.1111/0022-1082.00384

Coombes, P., \& Watson, M. (2000). Three surveys on corporate governance. The McKinsey Quarterly, (4).

Dawad, J. (2009). The Effect of internal corporate governance mechanisms on corporate performance.

Dey, A. (2005). Corporate Governance and Financial Reporting Credibility. Phd, Illinois, North Western University.

Eisenhardt, K. M. (1989). Agency Theory: An Assessment and Review. Academy of Management Review, 14, 57-74. https://doi.org/10.5465/amr.1989.4279003

Garmaise, M., \& Liu, J. (2004). Corruption, Firm Governance, and the Capital cost. Working paper, UCLA. https://doi.org/10.2139/ssrn.644017

Gebhardt, W. R., Lee, C. M. C., \& Swaminathan, B. (2001). Toward an implied capital cost. Journal of Accounting Research, 39, 135-176. https://doi.org/10.1111/1475-679X.00007

Gode, D., \& Mohanram, P. (2002). Inferring the capital cost using the Ohlson-Juettner model. Working paper, New York University 
Hollis, A., Daniel, W., \& Ryan, L. (2004). Corporate Governance and the Cost of Equity Capital.

Jaidi, O. (2007). The Level of Governance and its Impact on Corporate Performance", unpublished PhD thesis, Arab Academy for Banking and Financial Sciences, Amman, Jordan

Jensen, M., \& Meckling, W. (1976). Theory of the firm: Managerial behavior, agency costs and ownership structure. Journal of Financial Economics, 3, 305-360. https://doi.org/10.1016/0304-405X(76)90026-X

Joseph, A. (2012). The Effect of Determinants of Ownership Structure in the Holding of Financial Reports. Damascus University Journal of Economic and Legal Sciences, 28(1).

Kevin, C., Chen, A., Zhihong, C., \& John, W. (2009). Legal protection of investors, corporate governance, and the cost of equity capital. Journal of Financial and Quantitative Analysis, 48, 849-885.

Khoury, N. (2003). Where does Jordan stand from institutional control? Journal of Economic Policy Dialogue, 6 , 3-5.

Klapper, L. F., \& Love, I. (2002). Corporate governance, investor protection, and performance in emerging markets. World bank policy research working paper 2818. https://doi.org/10.2139/ssrn.303979

Matar, M., \& Noor, A. N. (2007). The extent of commitment of Jordanian public shareholding companies to the principles of corporate governance (comparative analysis between the banking and industrial sectors). Jordanian Journal of Business Administration, 3, 21.

Ohlson, J. A., \& Juettner-Nauroth, B. E. (2005). Expected EPS and EPS growth as determinants of value. Review of Accounting Studies, 10, 349-365. https://doi.org/10.1007/s11142-005-1535-3

Padilla, A. (2002). Can Agency Theory Justify The Regulation Of Insider Trading. The Quarterly Journal of Austrian Economics, 5(1), 3-38. https://doi.org/10.1007/s12113-002-1015-6

Ross, S. (1973). The Economic Theory of Agency: The Principal's Problem. The American Economic Review, 63(2), 134-139.

\section{Appendix}

Appendix 1 . The vocabulary of measuring the level of the elements of corporate governance

\begin{tabular}{ll}
\hline Board of Directors & 1 \\
\hline The Chairman of the Board is independent of the Executive Management of the Company & 2 \\
The board of directors is completely independent of the executive management of the company & 3 \\
The Audit Committee is independent of the Company's executive management & 4 \\
The remuneration and remuneration committee is independent of the executive management of the company & 5 \\
The external auditor is independent and has no relationship with the company & 6 \\
There are representatives of the banks or any lenders on the Board of Directors & 7 \\
The Board of Directors and Senior Management of the Company shall address and take care of the issues of shareholders & 1 \\
\hline Internal Control & 2 \\
\hline The audit committee is separate from the executive management of the company & 3 \\
There is a separation between tasks in the company & 4 \\
There is a separation between records and assets in the company & 5 \\
Internal control is directly linked to the Board of Directors & 6 \\
The Audit Committee of the company is able to supervise and follow up the internal control & 1 \\
The Audit Committee nominates the External Auditor & 2 \\
\hline Disclosure & 3 \\
\hline Financial reports are issued at the end of the year on time & 4 \\
The interim financial statements are issued on time & 5 \\
The financial statements are prepared in accordance with international accounting principles and standards \\
Financial reporting is the sole source of information about the company & 6 \\
The financial objectives of the company are disclosed & 7 \\
The results of the financial period are disclosed on time & 8 \\
The company's website information is updated continuously & \\
All relatively important financial events are disclosed & \\
\hline
\end{tabular}

\section{Copyrights}

Copyright for this article is retained by the author(s), with first publication rights granted to the journal.

This is an open-access article distributed under the terms and conditions of the Creative Commons Attribution license (http://creativecommons.org/licenses/by/4.0/). 